\title{
OPTIMIZATION OF KOTO JAYA DAILY MARKET PRODUCTION IN MUKOMUKO
}

\section{OPTIMALISASI PENDAYAGUNAAN PASAR HARIAN KOTO JAYA DI MUKOMUKO}

\author{
Yoki Kurniawan'); Rahmat Al Hidayat ${ }^{2)}$ \\ ${ }^{1)}$ Study Program of Business Administration, Sekolah Tinggi Ilmu Administrasi Bengkulu \\ 2) Lecturer, Program of Business Administration, Sekolah Tinggi Ilmu Administrasi Bengkulu \\ Email: ${ }^{1)}$ kurniawanyoki17@gmail.com; ${ }^{2)}$ yynrahmad@gmail.com
}
How to Cite :
Kurniawan.Y dan Hidayat.R.A. (2020). Optimalisasi Pendayagunaan Pasar Harian Koto Jaya Di Mukomuko. Bima Journal: Bussines Managemet and Accounting, 1(1).

\section{ARTICLE HISTORY \\ Received [10-01-2020] \\ Revised [15-01-2020] \\ Accepted [16-02-2020]}

\section{KEYWORDS}

Strategy, Strengths,

Weaknesses,

Opportunities and Threats

This is an open access article under the $C C-B Y-S A$ license

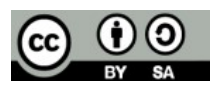

\begin{abstract}
ABSTRAK
Penelitian ini bertujuan untuk mengidentifikasi faktor-faktor internal dan eksternal yang dihadapi Pasar Harian Koto Jaya Di Mukomuko, menentukan strategi optimalisasi pendayagunaan pasar tersebut. Data yang digunakan dalam penelitian ini adalah data primer yang diperoleh dari pedagang di Pasar Harian Koto Jaya Di Mukomuko pada tahun 2018 dengan menggunakan alat analisis SWOT.

Hasil analisis dengan SWOT dapat disimpulkan bahwa faktor internal dalam optimalisasi pendayagunaan Pasar Harian Koto Jaya Di Mukomuko adalah; 1) Faktor Kekuatan (ketersediaan lahan, lokasi, fasilitas penunjang, organisasi pedagang, komposisi pedagang, infrastruktur, informasi harga); 2) Faktor kelemahan (harga sewa, utilitas, akses lokasi, kondisi pasar, keterbatasan anggaran, kesadaran pedagang), untuk faktor eksternal dalam optimalisasi pendayagunaan Pasar Harian Koto Jaya Di Mukomuko adalah; 1) Faktor peluang (jumlah penduduk, respon masyrakat, dukungan pemerintah, perkembangan teknologi); 2) Faktor ancaman (pesaing pasar lain, bencana alam, premanisme, kebijakan pemerintah, krisis ekonomi). Strategi yang harus diterapkan dalam kondisi ini adalah strategi WT (Weaknesses-Threats), yaitu; 1) Menerapkan strategi harga sewa kios dan los; 2) Meningkatkan kualitas dan mutu pelayanan Pasar Koto Jaya Mukomuko; 3) Mengoptimalkan sarana dan prasarana yang sudah ada; 4) Menjaga keamanan dan kenyamanan pasar.
\end{abstract}

\section{ABSTRACT}

This study aims to identify internal and external factors faced by the Koto Jaya Daily Market in Mukomuko, determine the optimization strategy of the market utilization. The data used in this study are primary data obtained from traders at the Koto Jaya Daily Market in Mukomuko in 2018 using a SWOT analysis tool.

The results of the SWOT analysis can be concluded that internal factors in optimizing the utilization of the Koto Jaya Daily Market in Mukomuko are; 1) Strength Factors (land availability, location, supporting facilities, trader organizations, merchant composition, infrastructure, price information); 2) Weakness factors (rental prices, utilities, location access, market conditions, budget constraints, trader awareness), for external factors in optimizing the utilization of the Koto Jaya Daily Market in Mukomuko are; 1) Opportunity factors (population, community response, government support, technological development); 2) Threat factors (other market competitors, natural disasters, thuggery, government policies, economic crisis). The strategy that must be applied in this condition is the WT (Weaknesses-Threats) strategy, namely; 1) Implement a kiosk and booth rental price strategy; 2) Improve the quality and service quality of the Koto Jaya Mukomuko Market; 3) Optimizing existing facilities and infrastructure; 4) Maintain market security and comfort. 


\section{PENDAHULUAN}

Pasar memiliki berbagai definisi yang berkembang, dari definisi yang ada pasar dapat didefinisikan sebagai suatu kelompok penjual dan pembeli yang mempertukarkan barang yang dapat disubstitusikan. Konsep dan pemaknaan pasar sesungguhnya sangat luas, mencakup dimensi ekonomi dan sosial-budaya. Dalam perspektif ekonomi pasar secara fisik diartikan sebagai tempat berlangsungnya transaksi barang dan jasa dalam tempat tertentu. Sedangkan secara ekonomi, pasar merupakan tempat atau wadah bertemunya permintaan dan penawaran, yaitu ada yang menawarkan barang dan ada yang menginginkannya dengan harga yang disepakati kedua belah pihak (Mariana dan Paskarina, 2006).

Dalam perspektif sosial-budaya, pasar merupakan tempat berlangsungnya interaksi sosial lintas strata. Dikotomi tradisional dan moderen yang dikenakan terhadap jenis pasar bersumber dari pergeseran pemaknaan terhadap pasar, yang semula menjadi ruang bagi berlangsungnya interaksi sosial, budaya, dan ekonomi kemudian tereduksi menjadi ruang bagi berlangsungnya transaksi ekonomi dan pencitraan terhadap modernisasi yang berlangsung dalam masyarakat (Mariana dan Paskarina, 2006).

Bagi sektor perdagangan, pasar merupakan tempat pedagang berusaha, sebagai sarana distribusi barang bagi produsen dan petani, tempat memonitor perkembangan harga dan stok barang beserta lapangan kerja bagi masyarakat luas. Sukesih (1994) menyatakan bahwa citra pasar dalam arti fisik telah mengalami banyak pembenahan dan peningkatan menjadi hal yang menarik seiring dengan kemajuan pembangunan ekonomi. Menariknya sarana tempat berdagang tersebut baik yang dikelola oleh pemerintah maupun swasta, ditentukan oleh pengelola pasar/tempat perdagangan dan tidak kalah pentingnya yang dilakukan/peranan pedagang itu sendiri. Pengelola hanya menyediakan fasilitas dan kemudahan untuk keperluan pedagang dan pengunjung, sedangkan para pedagang perlu memperhatikan kelengkapan Barang, display, kualitas barang, harga barang, kemudahan berbelanja, ketepatan ukuran.

Menurut Syahmora (2005), menyatakan pasar pada ukuran skala makro merupakan salah satu sektor penunjang perekonomian suatu kota. Pasar memiliki potensi untuk dikembangkan sebagai sumber peningkatan pendapatan daerah melalui pajak dan retribusi selain itu adanya imbas ekonomi dengan terjadinya kegiatan baru seperti sektor informal dalam pasar. Pasar dalam skala makro merupakan salahsatu penunjang kehidupan masyarakat dalam pemenuhan kebutuhan sehari-hari, pasar memiliki potensi untuk menampung tenaga kerja terutama untuk sektor informal.

Pemerintah Kabupaten Mukomuko dalam upaya meningkatkan kontribusi sektor perdagangan melalui peningkatan sarana dan prasarana perekonomian yaitu dengan dibangunnya pasar harian Koto Jaya. Pasar Koto Jaya tersebut telah dibangun pada tahun 2006 kemudian pada tahun 2007 diadakan penambahan sarana dan prasarana dalam pasar harian Koto Jaya tersebut. Pembangunan lokasi pasar tersebut menggunakan dana alokasi khusus (DAK) dengan total anggaran keseluruhan mencapai Rp. 2.720.347.500, luas bangunan dan sarana yaitu $1.539 \mathrm{~m} 2$. Bangunan pasar meliputi los yang berjumlah 135 unit, kios berjumlah 72 unit, sarana kebersihan (wc umum) berjumlah 2 unit, musholah 1unit, tempat pembakaran sampah 1 unit dan jalan masuk aspal. Berikut ini data gedung dan bangunan serta sarana prasarana yang ada di pasar harian tersebut:

Tabel 1. Data Jumlah Kios, Los dan Prasarana Pasar Harian Koto Jaya

\begin{tabular}{|l|l|c|l|}
\hline No & \multicolumn{1}{|c|}{ Jenis Sarana/Prasarana } & Ukuran (Luas) M2 & \multicolumn{1}{|c|}{ Jumlah } \\
\hline 1. & Kios Kuning & $4 \times 4$ & 40 unit \\
\hline 2. & Kios Hijau & $3 \times 3$ & 32 unit \\
\hline 3. & Los & $2 \times 3$ & 135 unit \\
\hline 4. & Musholah & 53 & 1 unit \\
\hline 5. & WC/Toilet & 12 & 2 unit \\
\hline 6. & Tempat Pembakaran Sampah & 16 & 1 unit \\
\hline 7. & Jalan masuk aspal & 420 & 1 paket \\
\hline
\end{tabular}

Sumber : Buku Aset Dinas Perindustrian dan Perdagangan Kab. Mukomuko (2012)

Berdasarkan hasil pengamatan di lapangan, pasar harian Koto Jaya dibangun bersebelahan dengan terminal dan berada pada lokasi yang strategis berada di jalan utama 
ISSN:

e-ISSN :

Kabupaten Mukomuko. Akan tetapi kenyataannya pasar tersebut tidak berjalan secara optimal, hal ini dapat ditunjukkan dari jumlah pedagang yang mengisi kios-kios yang tersedia di pasar harian Koto Jaya setiap hari. Tabel berikut menunjukkan Jumlah kios dan los yang dipakai oleh pedagang.

Tabel 2. Jumlah Kios Dan Los Yang Dipakai Oleh Pedagang

\begin{tabular}{|l|l|c|c|}
\hline No & Sarana (Gedung) & Jumlah & Jumlah aktif berdagang \\
\hline 1. & Kios & 72 & 17 \\
\hline 2. & Los & 135 & 1 \\
\hline
\end{tabular}

Sumber data: DisPerindagKop, 2013 (Data diolah)

Dari tabel diatas menunjukkan kurang optimalnya pendayagunaan pasar harian Koto Jaya tersebut karena dari jumlah kios yang tersedia yaitu 72 kios hanya 17 kios yang beroperasi atau aktif melakukan kegiatan penjualan setiap hari sedangkan los yang tersedia 135 los dan yang aktif hanya 1 los setiap harinya.

Menurut Thamrin dalam Harian Bengkulu Express 2012 menyatakan "dari segi bangunan pasar Koto Jaya tersebut tidak kalah dengan pasar yang ada di Kabupaten lainnya, bahkan los-los sudah sesuai standar, akan tetapi kurang berfungsinya pasar harian Koto Jaya tersebut harus dicari permasalahannya agar pasar yang telah dibangun tidak terbengkalai dan perekonomian masyarakat meningkat."

Ichwan Yunus dalam harian Radar Mukomuko 2013 menyatakan "pasar harian Koto Jaya harus benar-benar diwujudkan, dinas terkait harus cepat mempersiapkan segala komponen pendukung untuk mewujudkan pasar harian Koto Jaya tersebut."

Dari fakta-fakta yang telah diuraikan di atas, bahwa pasar harian Koto Jaya tidak berfungsi secara optimal sedangkan pembangunan pasar tersebut menggunakan dana APBD yang notabenenya adalah dana rakyat, kalau pasar tersebut tidak gunakan secara optimal maka dikhawatirkan akan beralih fungsi. Atas dasar tersebut maka penulis tertarik untuk melakukan penelitan mengenai "Optimalisasi Pendayagunaan Pasar Harian Koto Jaya".

\section{LANDASAN TEORI}

\section{Konsep Optimalisasi}

Menurut Kamus Besar Bahasa Indonesia Optimalisasi adalah berasal dari kata dasar optimal yang berarti terbaik, tertinggi, paling menguntungkan, menjadikan paling baik, menjadikan paling tinggi, pengoptimalan proses, cara, perbuatan mengoptimalkan (menjadikan paling baik, paling tinggi, dan sebagainya) sehingga optimalisasi adalah suatu tindakan, proses, atau metodologi untuk membuat sesuatu (sebagai sebuah desain, sistem, atau keputusan) menjadi lebih/sepenuhnya sempurna, fungsional, atau lebih efektif (kkbi.web.id).

Dalam penelitian ini optimalisasi pendayagunaan pasar harian Koto Jaya adalah usaha atau cara untuk memungsikan pasar harian Koto Jaya sesuai dengan peran dan fungsi suatu pasar.

\section{Pengertian Pasar}

Ginanjar (1980) menyatakan bahwa pasar adalah tempat untuk menjual dan memasarkan barang atau sebagai bentuk penampungan aktivitas perdagangan. Pasar pada mulanya merupakan perputaran dan pertemuan antara persediaan dan penawaran barang dan jasa. Sedangkan bagi Campbell (1990) mendefinisikan pasar sebagai institusi atau mekanisme di mana pembeli (yang membutuhkan) dan penjual (yang memproduksi) secara bersama-sama melakukan pertukaran barang dan jasa.

Tak berbeda seperti yang dipaparkan oleh Stanton (1996) dimana pasar merupakan tempat pembeli bertemu dengan penjual, di mana terdapat barang-barang atau jasa-jasa yang ditawarkan untuk dijual dan kemudian terjadi pemindahan hak milik. Selain itu dinyatakan pula bahwa pasar adalah sebagai tempat orang-orang yang mempunyai kebutuhan untuk dipuaskan, mempunyai uang untuk dibelanjakan dan kemauan untuk membelanjakan uang. 


\section{Harga}

Harga merupakan salah satu faktor penting yang mempengaruhi keputusan pembelian seseorang. Konsumen akan membeli suatu produk yang sesuai dengan kemampuan membelinya. Pedagang atau perusahaan harus memperhatikan hal ini, karena dalam persaingan harga yang ditawarkan pesaing bisa dengan harga yang lebih rendah dengan kualitas yang sama dan bisa juga dengan harga yang lebih tinggi. Untuk itu peranan harga sangat mempengaruhi optimalisasi pendayagunaan pasar harian Koto Jaya di Kabupaten Mukomuko.

Harga memiliki peranan utama dalam proses pengambilan keputusan (Tjiptono, 2000) yaitu:

1. Peranan alokasi harga

Fungsi harga dalam membantu para pembeli untuk memutuskan cara memperoleh manfaat atau utilitas tertinggi yang diharapkan berdasarkan daya belinya.

2. Peranan informasi dari harga

Fungsi harga dalam membidik konsumen mengenai faktor-faktor produk, seperti kualitas. Hal ini bermanfaat dalam situasi dimana pembeli mengalami kesulitan untuk menilai faktor produk atau manfaatnya secara objektif. Persepsi yang sering muncul adalah bahwa harga yang mahal mencerminkan kualitas yang tinggi sehingga konsumen menilai harga yang ditetapkan sesuai dengan kualitas produk maupun jasa yang ditetapkan.

\section{Permintaan}

Konsep permintaan mewakili perilaku konsumen secara umum di pasar. Perilaku konsumen dalam hal ini adalah faktor-faktor yang mempengaruhi jumlah permintaan suatu produk oleh konsumen dan bagaimana pengaruh dari perubahan faktor-faktor tersebut terhadap permintaan produk tersebut. Konsep permintaan menjelaskan bahwa permintaan aas suatu produk dipengaruhi oleh bauran pemasaran produk tersebut, bauran pemasaran produk pesaing, pendapatan konsumen, jumlah penduduk, ekspektasi konsumen, dan lain-lain (Herlambang, 2002).

\section{Penawaran}

Penawaran adalah salah satu kekuatan yang menentukan keseimbangan pasar. Penawaran pasar atas suatu produk menunjukkan total penawaran seluruh produsen yang ada di pasar, yang ditentukan oleh harga produk itu sendiri, harga produk lain, biaya produksi, teknologi, kebijakan pemerintah, besar pajak dan sbsidi, dan lain-lain. Jika harga suatu produk semakin murah, maka jumlah penawaran produk tersebut oleh produsen akan semakin kecil, demikian sebaliknya.sehingga dapat disimpulkan bahwa terdapat korelasi positif antara jumlah penawaran suatu produk dengan harganya dan jika digambarkan akan membentuk kurva penawaran. Kurva penawaran menunjukkan jumlah penawaran suatu produk pada berbagai tingkat harga, sementara faktor lain dianggap tetap (Herlambang, 2002).

\section{Fungsi dan Peranan Pasar}

Pasar merupakan akibat/hasil dari pola kegiatan manusia yang terjadi karena adanya saling membutuhkan, sehingga terjadi pola pertukaran antara barang dan jasa. Kompleksitas kebutuhan akan mengakibatkan kompleksitas jumlah orang, jenis barang, cara pertukaran dan membutuhkan tempat yang semakin luas (Kotler dan Amstrong, 2001). Fungsi pasar yang ada saat ini berdasarkan Keputusan Menteri Pekerjaan Umum Nomor 378/KPTS/1987 tentang Pengesahan 33 Standar Konstruksi Bangunan Indonesia, diuraikan sebagai berikut:

1. Pasar sebagai tempat pengumpul hasil pertanian.

Penjualan hasil-hasil pertanian seperti ketela, kool, kentang, beras dan lain-lain banyak terjadi di pasar, di mana proses pengumpulan hasil pertanian tersebut dilakukan di lokasi pertanian.

2. Pasar sebagai tempat distribusi barang industri. 
Pasar juga merupakan tempat distribusi barang-barang industri tertentu yang menyediakan peralatan rumah tangga yang diperlukan sebagai pelengkap dapur atau kebutuhan sehari-hari.

3. Pasar sebagai tempat menukar barang kebutuhan

Proses jual beli sering kali terjadi dengan tidak mempergunakan alat tukar (uang) tetapi dengan barang (barter). Proses ini terjadi akibat adanya kontak langsung antara penjual dan pembeli dan kuatnya faktor budaya atau kebiasaan dari penjual.

4. Pasar sebagai tempat jual beli barang dan jasa

Pasar berdasarkan fungsi ekonomisnya merupakan tempat jual beli barang dan jasa. Jasa disini tidak selalu berupa barang tetapi lebih merupakan tenaga keahlian atau pelayanan, misalnya tukang cukur, tukang parut, pembawa barang dagangan.

5. Pasar sebagai tempat informasi perdagangan

Pasar merupakan tempat informasi perdagangan karena di dalam pasar terjadi proses perputaran berbagai jenis barang, uang dan jasa. Jumlah barang atau jenis barang yang diperlukan atau yang beredar, harga yang berlaku sampai pada distribusi barang dapat diketahui melalui informasi pasar. Peran pasar terus meningkat sebagai akibat berkembangnya fungsi pasar saat ini. Pasar mempunyai peranan yang beragam berdasarkan pada pengertian-pengertian tentang pasar dan berkembangnya kegiatan-kegiatan yang terjadi di pasar.

\section{Matriks Strengths, Weaknesses, Opportunities and Threats (SWOT)}

Matriks SWOT digunakan untuk menggambarkan secara jelas bagaimana peluang dan ancaman yang dihadapi perusahaan dapat disesuaikan dengan kekuatan dan kelemahan yang dimiliki. Langkah-langkah matriks SWOT adalah dengan membuat:

1. Daftar peluang eksternal yang tersedia dalam lingkungan perusahaan saat ini dan yang akan datang.

2. Daftar ancaman eksternal yang dihadapi perusahaan saat ini dan yang akan datang.

3. Daftar bidang-bidang khusus kekuatan perusahaan saat ini dan yang akan datang.

4. Daftar kelemahan perusahaan saat ini dan akan datang.

5. Sekumpulan strategi yang mungkin bagi perusahaan.

Setelah mengumpulkan semua informasi dan melakukan analisis terhadap kondisi internal dan eksternal, selanjutnya adalah mengembangkan alternatif strategi. Perumusan strategi dapat dilakukan dengan menggunakan alat bantu matriks SWOT. Matriks ini dapat menggambarkan secara jelas peluang dan ancaman eksternal yang dihadapi lalu disesuaikan dengan kekuatan dan kelemahan yang ada. Formulasi strategi dengan matriks SWOT dapat menghasilkan empat kemungkinan strategi seperti yang dapat dilihat pada Tabel berikut.

Tabel 3. Matriks SWOT (Rangkuti, 2006)

\begin{tabular}{|c|c|c|}
\hline EFE IFE & Kekuatan ( S ) & Kelemahan ( W ) \\
\hline Peluang ( O ) & $\begin{array}{l}\text { Strategi SO } \\
\text { Menciptakan strategi } \\
\text { dengan memanfaatkan } \\
\text { seluruh kekuatan untuk } \\
\text { merebut } \\
\text { memanfaatkan peluang dan }\end{array}$ & $\begin{array}{l}\text { Strategi WO } \\
\text { Strategi berdasarkan } \\
\text { pemanfaatan peluang yang } \\
\text { ada dengan cara } \\
\text { meminimalkan kelemahan }\end{array}$ \\
\hline Ancaman ( $T$ ) & $\begin{array}{l}\text { Strategi ST } \\
\text { Strategi } \\
\text { menggunakan } \quad \text { yang } \\
\text { yang dimiliki perusahaan } \\
\text { untuk mengatasi ancaman }\end{array}$ & $\begin{array}{l}\text { Strategi WT } \\
\text { Strategi yang didasarkan } \\
\text { pada usaha meminimalkan } \\
\text { kelemahan dan } \\
\text { menghindari ancaman. }\end{array}$ \\
\hline
\end{tabular}

METODE PENELITIAN

\section{Metode Analisis}

Untuk menentukan strategi optimalisasi pendayagunaan pasar harian Koto Jaya di Kecamatan Kota Mukomuko digunakan analisis SWOT. Tahapan dalam menentukan strategi, 
yaitu mengidentifikasi faktor yang menjadi penyebab kurang optimalnya pendayagunaan pasar harian tersebut kemudian ditentukan kekuatan, kelemahan, peluang dan ancamannya.

\section{Faktor Internal}

1. Penampilan fisik

2. Utilitas (ketersediaan sarana listrik, air bersih, tempat pembuangan limbah)

3. Harga sewa kios dan los

4. Komposisi penduduk yang berbeda

5. Aksesibilitas lokasi

\section{Faktor Eksternal}

1. Penerimaan/respon masyarakat

2. Dukungan dari pemerintah daerah Kabupaten Mukomuko.

3. Sarana transportasi

4. Keterdekatan dengan pangsa pasar

5. Pesaing pasar lainnya

Tahapan kegiatan selanjutnya yang harus dilakukan adalah (Rangkuti, 2001).

1. Menyusun di dalam kolom 1 (5 sampai dengan 10) kekuatan dan kelemahan untuk faktor strategis internal serta peluang dan ancaman untuk faktor strategis eksternal.

2. Memberi bobot masing-masing faktor dalam kolom 2, mulai dari 1,0 (sangat penting) sampai dengan 0,0 (tidak penting). Di mana bobot yang diberikan menggambarkan seberapa penting faktor itu menunjang optimalisasi pendayagunaan pasar harian Koto Jaya di Mukomuko.

3. Menghitung rating (dalam kolom 3) untuk masing-masing faktor dengan memberikan skala mulai dari 4 (sangat tinggi) sampai dengan 1 (sangat kecil), berdasarkan pengaruh faktor terhadap organisasi. Nilai rating peluang dan ancaman selalu bertolak belakang, kalau faktor peluangnya lebih besar diberi nilai 4 sedangkan apabila faktor ancamannya lebih besar diberi nilai -4. Begitu pula pemberian nilai untuk kekuatan dan kelemahan.

4. Mengalikan bobot pada kolom 2 dengan rating pada kolom 3, untuk memperoleh faktor pembobotan dalam kolom 4 . Hasilnya untuk masing-masing faktor nilainya bervariasi mulai dari 4,0 (sangat baik) sampai dengan 1,0 (di bawah rata-rata).

5. Menggunakan kolom 5 untuk memberikan komentar atau catatan mengapa faktor-faktor dipilih dan bagaimana skor pembobotannya dihitung.

6. Menjumlahkan skor pembobotan (pada kolom 4) untuk memperoleh total skor pembobotan.

7. Menentukan letak kuadran berdasarkan jumlah skor pembobotan. 2001):

Adapun diagram yang menggambarkan analisis SWOT adalah sebagai berikut (Rangkuti,

\section{Gambar 1. Analisis SWOT}

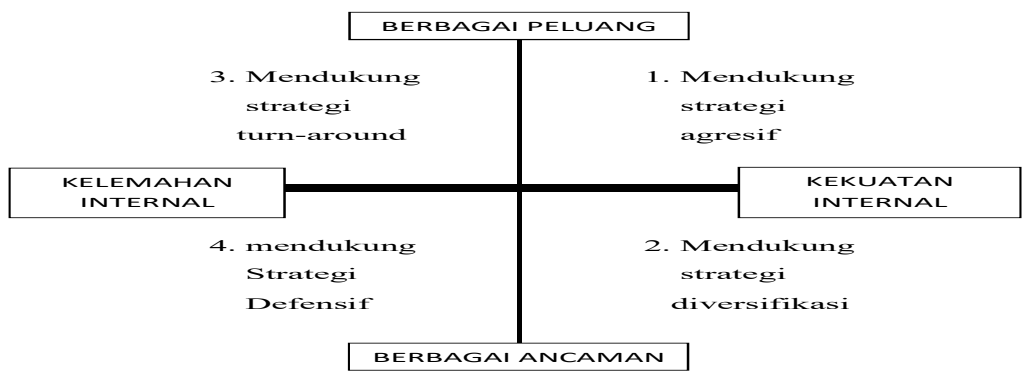

Kuadran 1: merupakan situasi yang menguntungkan. Pasar harian Koto Jaya di Mukomuko memiliki peluang dan kekuatan, sehingga memanfaatkan peluang yang ada. Strategi dalam kondisi ini adalah mendukung kebijakan pertumbuhan yang agresif (Strategi SO atau strategi kekuatan-peluang).

Kuadran 2: meskipun menghadapi berbagai ancaman, Pasar harian Koto Jaya ini memiliki kekuatan dari segi internal. Strategi yang dapat diterapkan adalah menggunakan kekuatan untuk memanfaatkan peluang jangka panjang (Strategi ST atau strategi kekuatan-ancaman). 
ISSN:

e-ISSN :

Kuadran 3: Pasar harian Koto Jaya menghadapi peluang pasar yang sangat besar, tetapi di lain pihak, Pasar harian Koto Jaya ini menghadapi beberapa kendala/kelemahan internal. Fokus strategi kawasan ini adalah meminimalkan masalah-masalah internal Pasar harian Koto Jaya sehingga dapat merebut peluang pasar yang lebih baik (Strategi WO atau strategi kelemahan-peluang).

Kuadran 4: ini merupakan situasi yang sangat tidak menguntungkan, Pasar harian Koto Jaya menghadapi berbagai ancaman dan kelemahan internal (Strategi WT atau strategi kekuatan-ancaman).

\section{HASIL DAN PEMBAHASAN}

\section{Analisis faktor optimalisasi pendayagunaan pasar harian Koto Jaya Mukomuko}

Analisis yang dilakukan bertujuan untuk mengetahui faktor optimalisasi pendayagunaan pasar harian Koto Jaya Mukomuko berdasarkan persepsi dan preferensi konsumen, pedagang, dan Pemerintah Kabupaten Mukomuko. Persepsi dan preferensi konsumen, pedagang dan Pemerintah Kabupaten Mukomuko didapatkan melalui kuesioner. Variabel-variabel yang diujikan dalam kuesioner tersebut merupakan hasil literatur.

Setelah mengetahui faktor-faktor optimalisasi pendayagunaan pasar harian Koto Jaya Mukomuko, maka dilakukan pembentukan strategi untuk bisa lebih mengembangkan pasar harian ini. Strategi adalah rencana aksi dalam suatu manajemen untuk melakukan kegiatankegiatan yang telah direncanakan. Hal yang menarik dalam strategi manajerial adalah komitmen untuk mencapai tujuan yang diharapkan dalam mengembangkan suatu kawasan, menarik dan memberikan kepuasan bagi konsumen, memiliki keunggulan bersaing, dan terus meningkatkan kinerja kawasan tersebut (Thompson et.al., 2008). Strategi yang dihasilkan dengan melihat faktor eksternal maupun internal yang akan diformulasikan dalam analisis SWOT, sebagai berikut.

\section{Faktor strategis eksternal faktor peluang (opportunities)}

Merupakan kesempatan yang didapatkan dari eksternal yang bersifat menguntungkan bagi proses pencapaian tujuan (Budiarto, 2011). Faktor peluang tersebut sebagai berikut.

1. Jumlah penduduk yang terus bertambah

2. Penerimaan atau respon masyarakat

3. Kedekatan dengan pangsa pasar

4. Adanya dukungan dari pemerintah daerah

5. Perkembangan teknologi

\section{Faktor strategis eksternal faktor ancaman (threats)}

Faktor yang dapat menghambat dan bersifat merugikan proses pencapaian tujuan yang diinginkan, hal ini berasal dari eksternal. Faktor ancaman adalah sebagai berikut.

1. Adanya pesaing pasar lain

2. Ancaman bencana alam

3. Aksi premanisme

4. Perubahan kebijakan pemerintah tentang pengembangan pasar

5. Kesesuaian dengan rencana tata ruang kota mukomuko

6. Adanya krisis ekonomi (inflasi)

Selanjutnya untuk mengetahui jumlah faktor strategis eksternal (peluang dan ancaman) maka dapat dilihat dalam tabel berikut ini. 
Tabel 4. Hasil Penilaian Faktor Eksternal (Data Diolah, 2018)

\begin{tabular}{|c|l|c|c|c|}
\hline No & \multicolumn{1}{|c|}{ Faktor eksternal } & Rating & Bobot & $\begin{array}{c}\text { Rating score } \\
\text { (rating X bobot) }\end{array}$ \\
\hline & Peluang & & 0,304 \\
\hline 1 & $\begin{array}{l}\text { Jumlah penduduk yang terus } \\
\text { bertambah }\end{array}$ & 3,04 & 0,1 & 0,321 \\
\hline 2 & $\begin{array}{l}\text { Penerimaan atau respon } \\
\text { masyarakat }\end{array}$ & 3,21 & 0,1 & 0,304 \\
\hline 3 & Kedekatan dengan pangsa pasar & 3,04 & 0,1 & 0,2547 \\
\hline 4 & $\begin{array}{l}\text { Adanya dukungan dari } \\
\text { pemerintah daerah }\end{array}$ & 2,83 & 0,09 & 0,2168 \\
\hline 5 & Perkembangan teknologi & 2,71 & 0,08 & \\
\hline \multicolumn{7}{|l|}{} & & & $-0,2466$ \\
\hline 1 & Ancaman & $-2,74$ & 0,09 & $-0,2312$ \\
\hline 2 & Ancaman bencana alam & $-2,89$ & 0,08 & $-0,27$ \\
\hline 3 & Aksi premanisme & -3 & 0,09 & $-0,2736$ \\
\hline 4 & $\begin{array}{l}\text { Perubahan kebijakan pemerintah } \\
\text { tentang pengembangan pasar }\end{array}$ & $-3,04$ & 0,09 & $-0,2296$ \\
\hline 5 & $\begin{array}{l}\text { Kesesuaian dengan rencana tata } \\
\text { ruang kota mukomuko }\end{array}$ & $-2,87$ & 0,08 & $-0,304$ \\
\hline 6 & Adanya krisis ekonomi (inflasi) & $-3,04$ & 0,1 & $-0,1545$ \\
\hline
\end{tabular}

Pada tabel di atas dapat dilihat bahwa jumlah skor untuk faktor strategis eksternal (peluang dan ancaman) untuk Pasar Koto Jaya Mukomuko adalah sebesar -0,15.

\section{Faktor strategis internal faktor kekuatan (strenghts)}

Merupakan faktor internal yang positif dan mendukung proses pencapaian tujuan. Hasil identifikasi yang menjadi faktor kekuatan adalah sebagai berikut.

1. Ketersediaan lahan termasuk luasnya

2. Terletak di lokasi yang stategis

3. Tersedia fasilitas dan akomodasi penunjang, misalnya: restoran, pos kesehatan, pos keamanan, sarana komunikasi

4. Memiliki organisasi pedagang

5. Komposisi pedagang yang berbeda

6. Memiliki infrastruktur dan aksebilitas yang baik

7. Menjaga solidaritas antara pengelola pasar, pedagang dan masyarakat

8. Sudah tersedia informasi harga untuk komoditas barang dagang

\section{Faktor strategis internal faktor kelemahan (weaknesses)}

Merupakan faktor yang negatif yang berasal dari internal, hal ini menghambat atau merugikan proses dalam pencapaian suatu tujuan. Faktor kelemahan tersebut adalah sebagai berikut.

1. Harga sewa kios dan los

2. Utilitas (ketersediaan sarana listrik, air bersih, tempat pembuangan limbah)

3. Aksesibilitas lokasi (ketersediaan jaringan jalan)

4. Kondisi atau penampilan fisik pasar

5. Keterbatasan dana dalam pengembangan pasar

6. Kurangnya kesadaran pedagang dalam ikut serta mengembangkan dan menjaga fasilitas pasar

Selanjutnya untuk mengetahui jumlah skor faktor strategis internal (kekuatan dan kelemahan) maka dapat dilihat pada tabel berikut ini. 
Tabel 5. Hasil Penilaian Faktor Internal (Data Diolah, 2018)

\begin{tabular}{|c|c|c|c|c|}
\hline No & Faktor internal & Rating & Bobot & $\begin{array}{c}\text { Rating score } \\
\text { (rating } X \text { bobot) }\end{array}$ \\
\hline & Kekuatan & & & \\
\hline 1 & Ketersediaan lahan termasuk luasnya & 3,29 & $\mathrm{O}, 08$ & 0,2632 \\
\hline 2 & Terletak di lokasi yang stategis & 3,08 & 0,08 & 0,2464 \\
\hline 3 & $\begin{array}{l}\text { Tersedia fasilitas dan akomodasi } \\
\text { penunjang, misalnya: restoran, pos } \\
\text { kesehatan, pos keamanan, sarana } \\
\text { komunikasi }\end{array}$ & 2,84 & 0,07 & 0,1988 \\
\hline 4 & Memiliki organisasi pedagang & 3,18 & 0,06 & 0,1908 \\
\hline 5 & Komposisi pedagang yang berbeda & 3,3 & $\mathrm{O}, 07$ & 0,231 \\
\hline 6 & $\begin{array}{l}\text { Memiliki infrastruktur dan aksebilitas } \\
\text { yang baik }\end{array}$ & 2,79 & O,08 & 0,2232 \\
\hline 7 & $\begin{array}{l}\text { Menjaga solidaritas antara pengelola } \\
\text { pasar, pedagang dan masyarakat }\end{array}$ & 3,04 & 0,06 & 0,1824 \\
\hline 8 & $\begin{array}{l}\text { Sudah tersedia informasi harga untuk } \\
\text { komoditas barang dagang }\end{array}$ & 2,91 & O,07 & 0,2037 \\
\hline & Kelemahan & & & \\
\hline 1 & Harga sewa kios dan los & $-2,8$ & $\mathrm{O}, 08$ & $-0,224$ \\
\hline 2 & $\begin{array}{l}\text { Utilitas (ketersediaan sarana listrik, } \\
\text { air bersih, tempat pembuangan } \\
\text { limbah) }\end{array}$ & $-2,82$ & 0,08 & $-0,2256$ \\
\hline 3 & $\begin{array}{l}\text { Aksesibilitas lokasi (ketersediaan } \\
\text { jaringan jalan) }\end{array}$ & $-3,16$ & 0,07 & $-0,2212$ \\
\hline 4 & Kondisi atau penampilan fisik pasar & $-2,95$ & $\mathrm{O}, 07$ & $-0,2065$ \\
\hline 5 & $\begin{array}{l}\text { Keterbatasan dana dalam } \\
\text { pengembangan pasar }\end{array}$ & $-3,23$ & 0,06 & $-0,1938$ \\
\hline 6 & $\begin{array}{l}\text { Kurangnya kesadaran pedagang } \\
\text { dalam ikut serta mengembangkan dan } \\
\text { menjaga fasilitas pasar }\end{array}$ & $-2,87$ & 0,07 & $-0,2009$ \\
\hline
\end{tabular}

Pada tabel di atas dapat dilihat bahwa jumlah skor faktor strategis internal (kekuatan dan kelemahan) untuk Pasar Koto Jaya adalah sebesar 0,47.

Berdasarkan tabel hasil penilaian faktor eksternal dapat dilihat bahwa jumlah skor faktor strategis eksternal sebesar $-0,15$ dan pada tabel hasil penilaian faktor internal dapat dilihat bahwa jumlah skor faktor strategi internal sebesar 0,47 maka hasil analisis SWOT yang didapatkan, jika dimasukkan ke dalam grafik maka akan seperti gambar berikut ini.

Gambar 2. Hasil Analisis SWOT (data diolah, 2018)

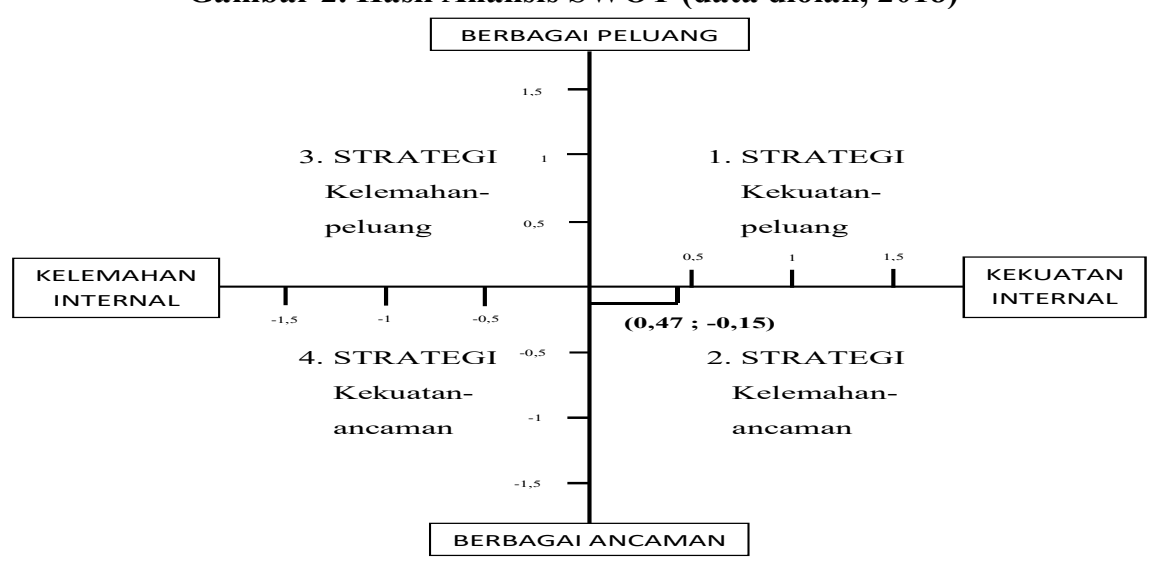

Dari peta SWOT tersebut di atas dapat dilihat bahwa posisi SWOT berada pada kuadran 2 Meskipun menghadapi berbagai ancaman, Pasar Koto Jaya Mukomuko masih memiliki kekuatan dari segi internal. Strategi yang harus diterapakan adalah menggunakan kekuatan untuk memanfaatkan peluang jangka panjang dengan cara strategis diversifikasi (produk atau pasar).

Alat yang dipakai untuk menyusun faktor-faktor strategis Pasar Koto Jaya Mukomuko adalah matrik SWOT. Matrik ini dapat menggambarkan secara jelas bagaimana peluang dan ancaman eksternal yang dihadapi Pasar Koto Jaya Mukomuko dapat disesuaikan dengan kekuatan dan kelemahan yang dimilikinya. Analisis Matrik SWOT berikut ini dapat menghasilkan empat set kemungkinan alternatif strategis, seperti pada tabel berikut (Rangkuti, 2006): 
Tabel 6. Matrik Analisis SWOT Untuk Merumuskan Alternatis Strategi

\begin{tabular}{|c|c|c|}
\hline Faktor eksternal & $\begin{array}{l}\text { Kekmatan (strenghts) } \\
\text { 1. Ketersediaan lahan termasulk luasnya } \\
\text { 2. Terletak di lokasi yang stategis } \\
\text { 3. Tersedia fasilitas dan akomodasi pemmjang, } \\
\text { misalnya restoran, pos kesehatan, pos } \\
\text { keamanan, sarana kommikasi } \\
\text { 4. Memiliki organisasi pedagang } \\
\text { 5. Komposisi pedagang yang berbeda } \\
\text { 6. Memiliki infrastruktur dan aksebilitas yang } \\
\text { baik } \\
\text { 7. Menjaga solidaritas antara pengelola pasar, } \\
\text { pedagang dan masyarakat } \\
\text { 8. Sudah tersedia informasi harga untuk } \\
\text { komoditas barang dagang }\end{array}$ & $\begin{array}{l}\text { Kelemahan (meaknesses) } \\
\text { 1. Harga sewa kios dan los } \\
\text { 2. Utilitas (ketersediaan sarana } \\
\text { listrik, air bersih, tempat } \\
\text { pembuangan limbah) } \\
\text { 3. Alcsesibilitas lokasi (ketersediaan } \\
\text { jaringan jalan) } \\
\text { 4. Kondisi atau penampilan fisik } \\
\text { pasar } \\
\text { 5. Keterbatasan dana dalam } \\
\text { pengembangan pasar } \\
\text { 6. Kurangnya kesadaran pedagang } \\
\text { dalam ikut serta mengembangkan } \\
\text { dan menjaga fasilitas pasar }\end{array}$ \\
\hline $\begin{array}{l}\text { Peluang (opportunities) } \\
\text { 1. Jumlah penduduk yang } \\
\text { terus bertambah } \\
\text { 2. Penerimaan atau respon } \\
\text { masyarakat } \\
\text { 3. Kedekatan dengan pangsa } \\
\text { pasar } \\
\text { 4. Adanya dukungan dari } \\
\text { pemerintah daerah } \\
\text { 5. Perkembangan teknologi }\end{array}$ & $\begin{array}{l}\text { Strategi SO } \\
\text { 1. Pelebaran dan pengembangan pasar } \\
\text { 2. Penambahan dan perbaikan fasilitas, } \\
\text { akomodasi penunjang, dan infrastuktur pasar } \\
\text { 3. Selalu bekerja sama dengan pemerintah } \\
\text { daerah dan masyarakat sekitar untuk } \\
\text { pengembangan pasar } \\
\text { 4. Update harga komoditas barang dagang } \\
\text { 5. Memanfaatkan teknologi informasi untuk } \\
\text { memperkenalkan Pasar Koto Jaya Mukomuko }\end{array}$ & $\begin{array}{l}\text { Strategi WO } \\
\text { 1. Penyesuaian harga sewa kios dan } \\
\text { los } \\
\text { 2. Perbaikan fisik pasar dan utilitas } \\
\text { (ketersediaan sarana listrik, air } \\
\text { bersih, tempat pembuangan } \\
\text { limbah) } \\
\text { 3. Bekerjasama dengan pemerintah } \\
\text { daerah menarik investor dalam } \\
\text { pengembangan pasar }\end{array}$ \\
\hline $\begin{array}{l}\text { Ancaman (threats) } \\
\text { 1. Adanya pesaing pasar lain } \\
\text { 2. Ancaman bencana alam } \\
\text { 3. Aksi premanisme } \\
\text { 4. Perubahan kebijakan } \\
\text { pemerintah tentang } \\
\text { pengembangan pasar } \\
\text { 5. Kesesuaian dengan } \\
\text { rencana tata ruang kota } \\
\text { mukomuko } \\
\text { 6. Adanya krisis elkonomi } \\
\text { (inflasi) }\end{array}$ & $\begin{array}{l}\text { Strategi ST } \\
\text { 1. Promosi pasar ke pedagang di luar pasar } \\
\text { 2. Pembangunan kios dan los anti gempa } \\
\text { 3. Menjaga solidaritas antara pengelola pasar, } \\
\text { pedagang dan masyarakat untuk mencegah } \\
\text { dan meminimalisir hal-hal yang tidak } \\
\text { diinginkan } \\
\text { 4. Berdialog dengan pemerintah daerah untuk } \\
\text { pengembangan pasar ke depan } \\
\text { 5. Menjual barang dagang sesuai dengan harga } \\
\text { eceran tertinggi, tanpa manipulasi harga }\end{array}$ & $\begin{array}{l}\text { StrategiWT } \\
\text { 1. Menerapkan strategi harga sewa } \\
\text { kios dan los } \\
\text { 2. Meningkatkan kualitas dan mutu } \\
\text { pelayanan Pasar Koto Jaya } \\
\text { Mukomuko } \\
\text { 3. Mengoptimalkan sarana dan } \\
\text { prasarana yang sudah ada } \\
\text { 4. Menjaga keamanan dan } \\
\text { kenyamanan pasar }\end{array}$ \\
\hline
\end{tabular}

Berdasarkan tabel di atas matrik analisis SWOT tersebut di atas, maka strategi yang digunakan oleh Pasar Koto Jaya Mukomuko yaitu strategi WT atau strategi kelemahan dan ancaman. Menggunakan seluruh kekuatan internal Pasar Koto Jaya Mukomuko untuk merebut dan memanfaatkan peluang sebesar-besarnya. Solusi strategi tersebut yaitu:

1. Menerapkan strategi harga sewa kios dan los.

Seiring berkembangnya jumlah kios atau ruko yang berada di luar wilayah Pasar Koto Jaya Mukomuko. Pihak pengelolah pasar harus menentukan harga yang bisa terjangkau dan tidak memberatkan pihak pedagang, sehingga pengguna kios dan los di dalam pasar tidak lari atau pindah ke tempat lain.

2. Meningkatkan kualitas dan mutu pelayanan Pasar Koto Jaya Mukomuko.

Strategi ini dilakukan untuk menambah kenyamanan dan kualitas perdagangan di Pasar Koto Jaya Mukomuko. Sehingga konsumen yang berbelanja di sini tidak merasa bosan. Ketika banyak terjadi transaksi antara pedagang dan konsumen di pasar ini, otomatis nantinya akan menarik pedagang dari luar untuk membuka kios atau los di Pasar Koto Jaya Mukomuko.

3. Mengoptimalisasikan saran dan prasarana yang sudah ada

Sarana dan prasarana yang sudah ada hendaknya dipelihara dan dijaga dengan baik. Karena sarana dan prasarana merupakan salah satu daya tarik untuk pedagang dari luar masuk ke pasar tersebut.

4. Menjaga keamanan dan kenyamanan pasar.

Suasana aman dan nyaman merupakan faktor penentu para pedagang dapat betah bertransaksi di dalam pasar tersebut. 


\section{KESIMPULAN DAN SARAN}

\section{Kesimpulan}

1. Hasil analisis SWOT menunjukkan strategi pengembangan yang digunakan oleh Pasar Koto Jaya Mukomuko berada di kuadran 2. Hal ini dapat diinterpretasikan meskipun menghadapi ancaman, Pasar Koto Jaya Mukomuko ini masih memiliki kekuatan dari segi internal. Strategi yang harus diterapkan adalah menggunakan kekuatan untuk memanfaatkan peluang jangka panjang dengan strategi diversifikasi (produk atau pasar).

2. Strategi yang harus diterapkan dalam kondisi ini adalah strategi WT (Weaknesses-Threats) atau strategi kekuatan-peluang. Strategi tersebut adalah:

(i) Menerapkan strategi harga sewa kios dan los

(ii) Meningkatkan kualitas dan mutu pelayanan Pasar Koto Jaya Mukomuko

(iii) Mengoptimalkan sarana dan prasarana yang sudah ada

(iv) Menjaga keamanan dan kenyamanan pasar

\section{Saran}

1. Dalam pembangunan, pemasaran, dan pengembangan Pasar Koto Jaya Mukomuko pemerintah harus mempertimbangkan preferensi para pengguna pasar baik pedagang dan konsumen pasar. Bukan hanya berdasarkan keinginan pihak pemrintah daerah saja.

2. Pedagang harus meningkatkan pelayanan dan kreatif dalam memasarkan komoditas barang dagangnya, supaya dapat memancing animo masyarakat, baik masayarakat Kota Mukomuko maupun masyarakat dari luar daerah Mukomuko untuk datang dan belanja di Pasar Koto Jaya Mukomuko.

3. Pedagang dan konsumen harus merasa bangga memiliki pasar harian Koto Jaya Mukomuko, oleh karena itu diharapkan pedagang dan konsumen dapat memelihara fasilitas yang sudah ada dan tidak melakukan pengrusakan terhadap fasilitas pasar yang telah dibuat.

\section{DAFTAR PUSTAKA}

Arsyad, L. 2000. Ekonomi Manajerial. BPFE. Yogyakarta.

Badan Pusat Statistik Kabupaten Mukomuko. 2011. Mukomuko Dalam Angka 2011. BPS Mukomuko

Blair, Jhon P. 1995. Local Economic Development, Analysis and Practice. California, USA: Sage Publications Inc.

Budiarto, Andreas. 2011. Analisis Sistem Perawatan Aset Operasional Medis RS. Panti Rapih Yogyakarta. Tesis S-2. Program Studi Magister Ekonomika Pembangunan, Fakultas Ekonomika dan Bisnis. Universitas Gadjah Mada. Yogyakarta. Tidak dipublikasikan.

Campbell, R. Mc Conned and Stanley L brue. 1990. Economic, Problem and Policie. Mc Graw Publishing Company.

Daldjoeni, Nathaniel. 1997. Geografi Baru Organisasi Keruangan Dalam Teori dan Praktek. Penerbit Alumni. Bandung.

Damsar. 1997. Sosiologi Ekonomi. Penerbit PT. Raja Grafindo Persada Jakarta.

David, R. 2004. Manajemen Strategis. PT. Prenhallindo. Jakarta.

De Chiara, Joseph dan E Lee Koppelman. 1997. Standar Perencanaan Tapak. Penerbit PT. Erlangga. Jakarta.

Dewar, David and Vanessa Watson.1990. Urban Market Developing Informal Retailing. London: Rontledge.

Dinas Perindustrian, Perdagangan dan Koperasi, 2012. Laporan Aset. Pemerintah Kabupaten Mukomuko.

Djojodipuro, Marsudi. 1992. Teori Lokasi. Lembaga Penerbit Fakultas Ekonomi Universitas Indonesia. Jakarta.

Galion, Arthur and Simon Eisner. 1994. The Urban Pattern, 3rd Edition. New York. 
ISSN:

e-ISSN :

Gallion, A.B dan Simon Eisner, 1996, Pengantar Perancangan Kota, Jilid I, Terjemahan Susongko dan Januar Hakim. Jakarta: Galia Indonesia.

Gibson, James L., et.al., terjemahan Nunuk Adiarni, 1996, Organisasi: Perilaku, StrukturProses,. Edisi ke delapan, Jakarta: Binarupa Aksara.

Harian Bengkulu Express. Senin 5 November 2012

Harian Radar Mukomuko. Senin 25 Februari 2013

Herlambang, T. 2002. Ekonomi Manejerial dan Strategi Bersaing. PT. Raja Grafindo Persada. Jakarta.

Istiningtyas, Arum Dyah. 2008. Analisis kebijakan dan strategi Pengembangan Pasar Tradisional Di Kota Bogor. Skripsi. Institut Pertanian Bogor.

Keputusan Menteri Pekerjaan Umum Nomor: 378/KPTS/1987 Tentang Pengesahan 33 Standar Konstruksi Bangunan Indonesia.

Keputusan Menteri Perindustrian dan Perdagangan Nomor: 23/MPP/KEP/1/1998 Tentang Lembaga-lembaga Usaha Dagang Perdagangan.

Kinnear, Thomas C. and James R. Taylor. 1995. Marketing Research: An Applied Approach. McGraw Hill Text.

Kotler, Philip and Donald H Hauder, Irving Rein. 1998. Marketing Places: Attracting Investment, Industry and Tourism To Cities, States and Nations. The Free Press Adivission of Macmillan Inc. New York.

Kotler, Philip dan Gary Armstrong. 2001. Prinsip-Prinsip Pemasaran, Erlangga. Jakarta.

Kotler, Philip dan Gary Armstrong. 2008. Prinsip-Prinsip Pemasaran, Erlangga. Jakarta.

Mankiw, N. G. 2000. Pengantar Ekonomi Jilid I. Erlangga. Jakarta.

Mariana dan Paskarina. 2006."Menggagas Model Revitalisasi Pasar Tradisional: Studi Terhadap Implementasi Perda No.19 Tahun 2001 Tentang Pengelolaan Pasar Kota Bandung”. Puslit KP2W Lemlit UNPAD, Bandung.

Millers, Roger Le Roy and Meiners, Roger. E. 2000. Teori Mikroekonomi Intermediate. Edisi Keempat. PT. Raja Grafindo. Jakarta.

Mursid, M. 1997. Manajemen Pemasaran. Penerbit: Bumi Aksara. Jakarta.

Nicholson, W. 2002. Intermediate Microeconomics and Its Application. Eight Edition. Harcount, Inc. New York.

Rangkuti, Freddy, 2001, Analisis SWOT Teknik Membedah Kasus Bisnis. Jakarta: Penerbit PT Gramedia Pustaka Utama.

Rangkuti, Freddy. 2006. Analisis SWOT Teknik Membedah Kasus Bisnis. Jakarta: Penerbit PT Gramedia Pustaka Utama.

Ristyanto, Yanuar. 2004. Evaluasi Alternatif Lokasi Pasar Induk Sayur Di Kota Surabaya, Tugas Akhir Tidak Diterbitkan. Teknik Perencanaan Wilayah dan Kota. Universitas Diponegoro. Semarang.

Samuelson, P. A dan W. D. Nordhaus. 2001. Ilmu Ekonomi. PT. Media Global Edukasi. Jakarta.

Sevilla, Consuelo et. Al. 1993. Pengantar Metode Penelitian. Terjemahan Alimuddin Tuwu. Universitas Indonesia. Jakarta.

Soesilo, Nining, J. 2000. Ekonomi, Perencanaan dan Manajemen. Universitas Indonesia. Jakarta.

Stanton, William J. 1996. Prinsip Pemasaran. Penerbit: Erlangga. Jakarta.

Sukesih, H. 1994."Pasar Swalayan dan Prospeknya". Jurnal Ekonomi dan Pembangunan No.2:63-68.

Sumaatmadja, Nursid. 1998. Studi Geografi, Suatu Pendekatan dan Analisa Keruangan. Penerbit: Alumni. Bandung.

Swastha, Basu DH. 2010. Manajemen Penjualan. Penerbit: BPFE. Yogyakarta.

Syahmora, Abi. 2005. Lokasi Optimal Pembangunan Pasar di Kota Lahat Berdasarkan Kajian Faktor-Faktor Lokasi Penentu Pasar. Thesis. Universitas Diponegoro.

Thompson, Arthur A., Jr., A.J Strickland III, and John E. Gamble. 2008. Crafting and Executing Strategy (The Quest for Competitive Advantage Concepts and Cases). 16th edition. McGraw-Hill.

Tjiptono, Fandy. 2000. Prinsip-Prinsip Total Quality Service. Penerbit: Andi. Yogyakarta.

Tjiptono, Fandy. 2008. Pemasaran Jasa. Penerbit: Bayu Media Publishing. Malang. 